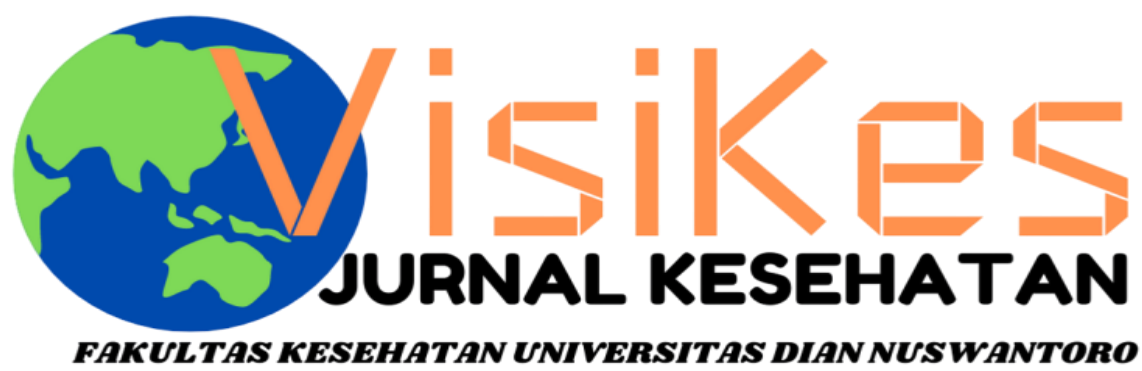

ISSN 1412-3746

FAKULTAS KESEHATAN UNIVERSITAS DIAN NUSWANTORO

Persepsi Mahasiswa Keperawatan Tentang Eskalasi Tenaga Perawat

Rendi Ariyanto Sinanto', Vivi Retno Intening ${ }^{2}$

Risiko kesehatan $\mathrm{Pb}$ dan $\mathrm{Hg}$ pada sayuran di desa Kopeng Kabupaten Semarang

Indira Casheila Anindityo ${ }^{1}$, Nur Endah Wahyuningsih ${ }^{2}$, Yusniar Hanani Darundiati ${ }^{3}$

Analisis Pelaksanaan Program Indonesia Sehat Dengan Pendekatan Keluarga (Pispk) Dalam Capaian Indeks Keluarga

Sehat Di Kabupaten Brebes Tahun 2020 Studi Pada Puskesmas Kluwut Kabupaten Brebes

Rizky Aprilianti Lestari ${ }^{1}$ dr. Antono Suryoputro ${ }^{1}$ Dr. dr. Apoina Kartini. M. Kes ${ }^{1}$

Disiplin Keselamatan dan Kesehatan Kerja melalui pemakaian alat pelindung diri di laboratorium kimia PT Sucofindo

Jakarta

Susan Endah Kartikasari ${ }^{1}$, Tatan Sukwika ${ }^{2}$

Perbedaan Pengetahuan Anemia dan Tablet Tambah Darah (TTD) Sebelum dan Sesudah Pendidikan Kesehatan Melalui

Media Video dan Aplikasi Quizlet

Devita Sari ${ }^{1}$, Gisely Vionalita ${ }^{2}$

Tingkat Pengetahuan Dan Perilaku Mahasiswi Mengenai Legalitas Dan Keamanan Kosmetik

Hani Sri Fitriani, Rizki Siti Nurfitria

Evaluasi Manajemen Dokumen Rekam Medis Di Filing Aktif Rumah Sakit Swasta Kabupaten Semarang

Bobby Anggara Laksana Putra ${ }^{1}$, Retno Astuti Setjaningsih ${ }^{2}$

Tingkat Pengetahuan Gizi Seimbang dan Profil Kesehatan Sopir Bus Antar Kota

Vilda Ana Veria Setyawati ${ }^{1}$, Bayu Yoni Setyo Nugroho ${ }^{1}$

Pengaruh Pengetahuan Dan Motivasi Kerja Terhadap Penerapan Early Warning Score System Di Rsup H Adam Malik Ita Riahna Pinem ${ }^{1}$, Zulfendri', Siti Saidah Nasution ${ }^{3}$

Analisis Penelusuran Masker Sebagai Protokol Kesehatan Saat Pandemi Covid-19 Di Indonesia: Studi Google Trends Ully Febra Kusuma ${ }^{1}$, Nurunnisa Arsyad ${ }^{2}$, Melissa Shalimar Lavinia ${ }^{3}$, Selvia Rahayu ${ }^{4}$, M. Khairul Kahfi , Rizma Adllia Syakurah ${ }^{6}$ Perilaku Hidup Bersih Dan Sehat (Phbs) Dengan Kejadian Sakit Pada Siswa Sekolah Dasar Di Kabupaten Banyumas Windri Lesmana Rubai ${ }^{1}$, Pramesthi Widya Hapsari', Katri Andirini Surijati ${ }^{3}$

Identifikasi Risiko Ganguan Muskuloskletal Pada Pekerja Percetakan Dengan Metode Nordic Body Map

Octavianus Hutapea ${ }^{1}$, Moch.Sahri', Rustam Basuki ${ }^{3}$

Literatur review: Implementasi Bauran Pemasaran 7P Terhadap Tingkat Kepuasan Pasien Di Rumah Sakit

Desi Natalia Marpaung ${ }^{1}$ Ernawaty $^{2}$ Diansanto Prayoga ${ }^{3}$ Syifa'ul Lailiyah $^{4}$

Kelengkapan Informasi Medis Untuk Mendukung Kodefikasi Penyakit Jantung Guna Mewujudkan Kualitas Data Informasi Medis Di Rumah Sakit Islam Sultan Agung Semarang

Dyah Ernawati ${ }^{1}$, Ratna Rifatul Ulya ${ }^{2}$, Arif Kurniadi ${ }^{3}$

Kajian Faktor Kendala Dokter Tidak Menggunakan Aplikasi Wifi Tb Di Kota Semarang

Arif Kurniadi', Evina Widianawati2, Dyah Ernawati ${ }^{3}$

Analisis Pelaksanaan Program Penanggulangan Tuberkulosis Paru Di Puskesmas Purwoyoso Kota Semarang

Nahari Ratu Cempaka Wilis ${ }^{1}$ Hardi Warsono ${ }^{2}$ M. Sakundarno Adi ${ }^{3}$

Hubungan Penggunaan Alat Pelindung Diri (Apd) Dengan Kadar Sgot Dan Sgpt Dalam Darah Pada Petani Padi

Iga Maliga, Rafi'ah

Faktor Risiko Kejadian Stunting Pada Balita di Wilayah Kerja Puskesmas Pandan Kabupaten Sintang

${ }^{1}$ Agustini Elisabet, ${ }^{2}$ Elvi Juliansyah

Peran Suami Dan Petugas Kesehatan Dengan Deteksi Dini Kanker Serviks

Christina Leasa, ${ }^{1}$ Mariene Wiwin Dolang

Analisis Penerapan Protokol Kesehatan terhadap Tingkat Kepatuhan Pada Pekerja informal Selama Pandemi Covid-19

MG Catur Yuantari ${ }^{1}$, Enny Rachmani ${ }^{2}$, Eti Rimawati ${ }^{1}$, Sri Handayani ${ }^{1}$, Edi Jaya Kusuma ${ }^{2}$

Peran Pengawas Minum Obat Dan Pendampingan Berobat Ulang Dengan Keberhasilan Pengobatan Tb Paru

Taswin $^{\left.1^{*}\right)}$, (zan $^{1)}$, Wahyuddin $^{1)}$, Dahmar ${ }^{1)}$

Faktor Determinan Sosial Dan Gambaran Kejadian Post Traumatic Syndrome Disorder (Ptsd) Pasca Banjir Di Dki Jakarta

Dan Bekasi Tahun 2020

Thresya Febrianti ${ }^{1}$, Nurfadhillah ${ }^{2}$, Mitha Nurhjanah ${ }^{3}$, Tiara Kautsa Aliefya ${ }^{4}$

Perbedaan Pola Makan Pada Balita Stunting Dan Tidak Stunting Di Kecamatan Teon Nila Serua (Tns) Kabupaten Maluku Tengah

Trixie Leunupun ${ }^{1}$, Ani Margawati' ${ }^{2}$ Annastasia Ediati ${ }^{3}$

Gambaran Pengelolaan Rekam Medis Rawat Inap Di Rsud Syekh Yusuf Kab. Gowa Tahun 2019

Zilfadhilah Arranury*, Surahmawati, Muhammad Rusmin, Tri Addya Karini, Dian Rezki Wijaya, Ranti Ekasari, Jihan Sulfitri

Analisis Risiko Kesehatan dalam Pemanfaatan Kemball Limbah Sludge Industri Makanan PT. X

Sri Slamet Mulyati ${ }^{1}$, Fajar Sihite ${ }^{2}$ 


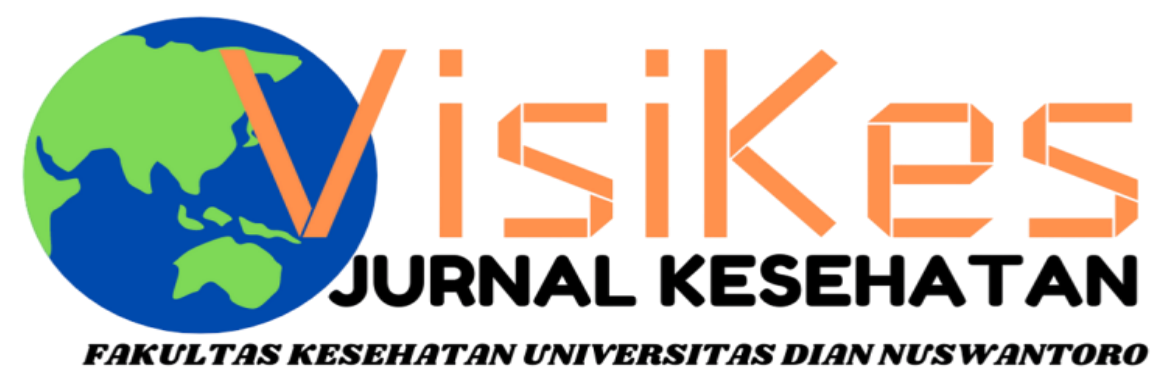

Volume 20, Nomor 1, April 2021

\section{Ketua Redaksi}

Dr. Drs. Slamet Isworo, M.Kes

\section{Penyunting}

Enny Rachmani, SKM, M.Kom, Ph.D

Fitria Wulandari, SKM, M.Kes

\section{Sekretariat}

Lice Sabata, SKM

Desain dan Layout

Puput Nur Fajri, SKM

\section{Alamat Redaksi}

Fakultas Kesehatan Universitas Dian Nuswantoro Jl. Nakula I No. 5-11 Semarang Telp/fax. (024) 3549948

email : visikes@fkes.dinus.ac.id

website $\quad$ : http://publikasi.dinus.ac.id/index.php/visikes/index

VisiKes diterbitkan mulai Maret 2002

Oleh Fakultas Kesehatan Universitas Dian Nuswantoro 


\title{
Tingkat Pengetahuan Dan Perilaku Mahasiswi Mengenai Legalitas Dan Keamanan Kosmetik
}

Hani Sri Fitriani, Rizki Siti Nurfitria

Fakultas Farmasi Universitas Bhakti Kencana Bandung

e-mail :hanisrifitriani98@gmail.com; rizki.sitinurfitria@bku.ac.id

\begin{abstract}
Cosmetic is secondary needs for human life and commodities used by all ages the rise of illegal cosmetics findings in community, increased promoting by public figures while safe cosmetics knowladge of community has not been balanced. The purpose of this study was to determine the level of knowledge and behavior regarding cosmetic legality and safety in students of health faculty including pharmacy and non-pharmacy in Bhakti Kencana University. The research methodology used was descriptive observational using cross-sectional approach. Data was analyzed both quantitatively and qualitatively. Data retrieval was done through filling out questionnaires that had been tested for validity and reliability. Data were analyzed by Rank Spearman test and MannWitney test. The results showed that the level of knowledge and behavior of pharmacy and non pharmacy was in the fair category (65,85\%) (56,09\%) and (67,47\%) (73,98\%). There was a weak and significant positive relationship between level of knowledge and behavior of cosmetic use in non-pharmacy student with correlation coefficient 0.133 so as pharmacy student not significant with correlation coefficient of 0.02. There was significant relationship between faculty with the level of knowledge and behavior cosmetic use of pharmacy faculty and non-pharmacy faculty with a correlation coefficient 0.000 and 0.003 .
\end{abstract}

Keywords: Cosmetic, Legal, Safe, Knowledge, Behavior

\begin{abstract}
ABSTRAK
Kosmetik merupakan kebutuhan sekunder dalam kehidupan masyarakat serta komoditi digunakan semua kelompok usia maraknya temuan kosmetik ilegal di masyarakat, makin banyak public figure yang turut mempromosikan produk kosmetik, belum diimbangi dengan tingkat pengetahuan mahasiswi mengenai kosmetik yang aman. Penelitian ini bertujuan untuk mengetahui tingkat pengetahuan dan perilaku penggunaan kosmetik pada mahasiswi jurusan kesehatan baik yang mencakup farmasi dan non-farmasi di Universitas Bhakti Kencana Bandung. Metodologi penelitian yang digunakan adalah observasional deskriptif menggunakan pendekatan potong lintang. Data dianalisis baik secara kuantitatif maupun kualitatif. Pengambilan data dilakukan melalui pengisian kuesioner yang telah diuji validitas dan reliabilitasnya. Data dianalisis dengan uji Rank Spearman dan uji Mann-withney. Hasil penelitian menunjukkan mahasiswi kesehatan farmasi maupun nonfarmasi memiliki tingkat pengetahuan dan perilaku cukup $(65,85 \%)(56,09 \%)$ dan $(67,47 \%)$ (73,98\%). Terdapat hubungan positif lemah dan signifikan antara tingkat pengetahuan dan perilaku penggunaan kosmetik pada mahasiswi fakultas non-farmasi dengan koefisien korelasi sebesar 0.133 begitupula dengan fakultas farmasi tidak signifikan dengan kolerasi sebesar 0.02 . Terdapat korelasi yang signifikan antara fakultas dengan pengetahuan dan perilaku penggunaan kosmetik pada mahasiswi farmasi dan non-farmasi dengan signifikansi yaitu 0,000 dan 0,003.
\end{abstract}

Kata Kunci: Kosmetik, Legal, Aman, Pengetahuan, Perilaku.

\section{PENDAHULUAN}

Kosmetik menjadi bisnis yang besar dengan nilai pasar global mencapai US\$ 500 miliar atau setara Rp 6.660 triliun. Global
Business Guide menyatakan bahwa di Indonesia, pertumbuhan volume penjualan industri kosmetik didongkrak oleh permintaan yang meninggi dari kelas menengah. 
Peredaran kosmetik dinamis terhadap perkembangan zaman. Pada era digital ini, perubahan gaya hidup, terutama tingginya penggunaan internet sangat mempengaruhi perubahan polaper dagangan kosmetik. Hal ini ditunjukkan dengan makin gencarnya pelaku usaha dalam melakukan promosi produk terutama di media online, salah satunya dengan melibatkan public figure ${ }^{(1)}$. Adanya motivasi untung besar, produsen memasarkan kosmetik tanpa melalui tahap penilaian dan registrasi pada instansi yang berwenang. Akibatnya, banyak kosmetik beredar di pasaran tanpa nomor izin edar (TIE) atau menggunakan nomor izin edar fiktif (palsu) ${ }^{(2)}$.

Menurut Asosiasi Produsen Kosmetik Indonesia (PPAKI), nilai penjualan kosmetik ilegal di Indonesia diperkirakan antara 15\%$20 \%$ dari total penjualan kosmetik di Indonesia dengan pertumbuhan dua digit per tahun $^{(3)}$. Sepanjang tahun 2018 pemusnahan obat dan kosmetik hasil pengawasan BPOM di Bandung Jawa Barat bernilai 8,1 miliar rupiah tingginya angka temuan kosmetik ilegal ini secara tidak langsung menunjukkan adanya demand yang tinggi dari masyarakat (4). Sepanjang tahun 2019, nilai keekonomian temuan kosmetik ilegal hingga bulan Agustus mencapai 31 miliar rupiah. Badan POM di Kabupaten Tangerang melakukan kegiatan penertiban kosmetik ilegal di sarana distribusi kosmetik ditemukan kosmetik tanpa izin edar yang merupakan produk impor dari negara Perancis, Italia, India, Spanyol, USA, UK, Jerman, Arab. Kosmetik yang diamankan berjumlah 214 item dengan total nominal mecapai 580 juta rupiah ${ }^{(1)}$.

Penggunaan kosmetik yang meningkat di Indonesia mendorong produsen membuat produk kosmetik dalam berbagai macam bentuk sediaan serta kandungan bahan kimia. Badan POM menyebutkan beberapa kriteria kosmetik yang dapat dikategorikan aman meliputi harus adanya kegunaan dan cara penggunaan, tidak terkandungnya bahan kimia berbahaya, label, kemasan, izin edar, dan tanggal kadaluarsa ${ }^{(2)}$.

Terdapat lebih dari 1.100 bahan yang digunakan dalam produk kosmetik menurut Environmental Working Group (EWG). Penggunaan 10 bahan dalam kosmetik telah dilarang oleh Food and Drug Administration (FDA) dan secara kompak ditentang oleh ahliahli dermatologi. Bahan kosmetik tersebut dapat mengganggu kesuburan bahkan memicu kanker atau bersifat karsinogenik diantaranya yaitu Oxybenzone, Formaldehyde, Timah, Triclosan, Hydroquinone, Parabens, Merkuri, Formalin, Phthalates dan Timbal ${ }^{(5)}$.

Konsumen wanita khususnya usia produktif adalah sasaran utama dari industri kosmetik (6). Mahasiswa adalah salah satu populasi di dalamnya dan merupakan pengguna kosmetik tertinggi ${ }^{(7)}$. Penelitian terhadap 3.814 wanita Inggris tahun 2010 yang dilakukan oleh Opinium Research di London menunjukkan bahwa $73 \%$ wanita sama sekali tidak memahami kandungan bahan yang tercantum dalam label kosmetik yang mereka beli ${ }^{(8)}$. Universitas Bhakti 
Kencana Bandung fakultas kesehatan mencakup farmasi dan non farmasi didominasi oleh mahasiswa perempuan karena itu peneliti tertarik untuk menggali pengetahuan dan perilaku penggunaan kosmetik serta korelasi pengetahuan dan perilaku penggunaan kosmetik dan hubungan fakultas dengan pengetahuan dan perilaku pada mahasiswi kesehatan baik farmasi maupu non-farmasi di Universitas Bhakti Kencana Bandung.

\section{METODE PENELITIAN}

Penelitian ini termasuk dalam kategori penelitian observasional, dengan pendekatan (cross-sectional). Penelitian dilakukan pada bulan Januari-Februari 2020 di kampus Unversitas Bhakti Kencana. Jumlah populasi menurut data kemahasiswaan, mahasiswi farmasi yang aktif sebanyak 637. Jumlah sampel masing-masing mahasiswi fakultas kesehatan baik yang mencakup farmasi dan non-farmasi Universitas Bhakti Kencana Bandung yaitu 246. Teknik pengambilan sampel dilakukan secara aksidental (accidental) menggunakan data primer berupa kuesioner.

Analisis yang digunakan adalah analisis univariat dan bivariat, analisis univariat meliputi distribusi umur, tempat membeli kosmetik langsung maupun online, pertimbangan memilih kosmetik, sumber informasi, dan informasi yang diperoleh terkait kosmetik. Mendeskripsikan variabel pengetahuan serta perilaku responden berdasarkan scoring pada setiap pertanyaan.
Setelah diketahui karakteristik dan distribusi setiap variabel, kemudian dilakukan analisis bivariat. Analisis bivariat digunakan untuk melihat variabel bebas yaitu pengetahuan mengenai keamanan dan legalits kosmetik dengan variabel terkait yaitu perilaku penggunaan kosmetik pada mahasiswi fakultas kesehatan baik yang mencakup farmasi dan non-farmasi di Universitas Bhakti Kencana Bandung.

Hasil pengujian menggunakan Rank Spearman dan Mann-Withney untuk melihat hubungan antara pengetahuan dengan perilaku penggunaan kosmetik dan hubungan anatara fakultas terhadap pengetahuan dan perilaku penggunaan kosmetik.

\section{HASIL}

Berdasarkan tabel 1 distribusi karakteristik umur tertinngi yaitu 18-23 tahun pada mahasiswi Kesehatan baik farmasi maupun non-farmasi $(96,34 \%$ dan $97,15 \%)$. Distribusi gambaran penggunaan kosmetik mahasiswi farmasi maupun non-farmasi tempat memperoleh kosmetik secara online yaitu Shopee ( $50 \%$ dan $71,95 \%$ ), tempat membeli kosmetik langsung tertinngi yaitu Mall (47,56 dan 59,34), pertimbangan pemilihan kosmetik terbanyak yaitu jenis kulit $(47,97$ dan 53,25) sumber informasi mahasiswi farmasi terkait kosmetik tertinggi berasal dari teman/keluarga $(39,83 \%)$ dan non-farmasi terbanyak bersumber dari instagram $(41,63 \%)$, informasi tertinngi yang diperoleh terkait keamanan kosmetik $(36,58 \%$ dan $29,67 \%$ ). 
Tabel 1. Distribusi Karakteristik, Gambaran Penggunaan Kosmetik, Frekuensi Tingkat Pengetahuan dan Perilaku

\begin{tabular}{|c|c|c|c|c|c|}
\hline \multirow[b]{2}{*}{ Variabel } & \multirow[b]{2}{*}{ Kategori } & \multicolumn{2}{|c|}{ Farmasi } & \multicolumn{2}{|c|}{ Non-farmasi } \\
\hline & & $\begin{array}{c}\text { Frekuensi } \\
(\mathrm{n}=246)\end{array}$ & $\begin{array}{c}\text { Persentase } \\
(\%)\end{array}$ & $\begin{array}{c}\text { Frekuensi } \\
(n=246)\end{array}$ & $\begin{array}{c}\text { Persentase } \\
(\%)\end{array}$ \\
\hline \multirow{3}{*}{ Umur } & $16-17$ & 3 & 0,87 & 4 & 1,6 \\
\hline & $18-23$ & 237 & 96,34 & 239 & 97,15 \\
\hline & $24-37$ & 6 & 2,44 & 3 & 1,22 \\
\hline & Sociolla & 24 & 9,75 & 23 & 9,34 \\
\hline Tempat membeli & Shopee & 123 & 50 & 177 & 71,95 \\
\hline \multirow{2}{*}{ kosmetik online } & Website terkait & 69 & 28,04 & 24 & 9,76 \\
\hline & Lainnya & 30 & 12,19 & 23 & 8,94 \\
\hline \multirow{5}{*}{ kosmetik langsung } & Apotek & 70 & 28,45 & 45 & 18,29 \\
\hline & Mall & 117 & 47,56 & 146 & 59,34 \\
\hline & Pasar & & & & \\
\hline & Tradisonal & 4 & 1,62 & 10 & 4,06 \\
\hline & Lainnya & 10 & 4,06 & 17 & 6,9 \\
\hline & Jenis kulit & 118 & 47,97 & 131 & 53,25 \\
\hline Pertimbangan & Harga & 45 & 18,29 & 10 & 24,06 \\
\hline \multirow[t]{3}{*}{ memilih kosmetik } & Aroma & 40 & 16,26 & 3 & 1,21 \\
\hline & Keamanan & 43 & 17,47 & 102 & 41,46 \\
\hline & $\begin{array}{l}\text { Teman/ } \\
\text { Keluarga }\end{array}$ & 98 & 39,83 & 78 & 31,13 \\
\hline \multirow[t]{6}{*}{ Sumber informasi } & Famel Daily & 30 & 12,19 & 20 & 8,13 \\
\hline & Website & 22 & 8,94 & 30 & 20,19 \\
\hline & Tv & 19 & 7,72 & 12 & 4,78 \\
\hline & Instagram & 28 & 11,38 & 102 & 41,63 \\
\hline & Seminar & 14 & 5,69 & 2 & 0,8 \\
\hline & Perkuliahan & 35 & 14,23 & 2 & 0,8 \\
\hline \multirow[t]{5}{*}{ Informasi kosmetik } & Keamanan & 90 & 36,58 & 73 & 29,67 \\
\hline & Harga & 36 & 14,63 & 40 & 16,26 \\
\hline & $\begin{array}{l}\text { Komposisi } \\
\text { Cara }\end{array}$ & 20 & 8,13 & 30 & 24,39 \\
\hline & penggunaan & 20 & 8,13 & 43 & 17,48 \\
\hline & Legalitas & 80 & 32,52 & 60 & 2,19 \\
\hline \multirow{3}{*}{ Pengetahuan } & Kurang & 68 & 27,64 & 37 & 15,04 \\
\hline & Cukup & 162 & 65,85 & 138 & 56,09 \\
\hline & Baik & 16 & 6,50 & 71 & 28,86 \\
\hline \multirow{3}{*}{ Perilaku } & Kurang & 36 & 14,63 & 45 & 18,30 \\
\hline & Cukup & 166 & 67,47 & 182 & 73,98 \\
\hline & Baik & 44 & 17,88 & 19 & 7,72 \\
\hline Total & & 246 & 100 & 246 & 100 \\
\hline
\end{tabular}

Diketahui dari tabel 1 mahasiswi farmasi dan Kesehatan non-farmasi memiliki pengetahuan yang cukup $(65,85 \%$ dan
$56,09 \%$ ) dengan tingkat perilaku cukup $(67,47 \%$ dan $73,98 \%)$. 
Tabel 2. Hasil Uji Rank Spearman Pengetahuan terhadap Perilaku

\begin{tabular}{cccccccc}
\hline & & \multicolumn{3}{c}{ Farmasi } & \multicolumn{3}{c}{ Non-farmasi } \\
\cline { 3 - 7 } Variabel & VariabelT & $\mathrm{P}$ & Tingkat & Rho & $\mathrm{P}$ & Tingkat & Rho \\
Bebas & erkait & Value & Korelasi & & Value & Korelasi & \\
\hline Pengetahuan & Perilku & $0,755>$ & Sangatl & 0,02 & $0.037<$ & Sangatle & 0,133 \\
& & 0,05 & emah & & 0,05 & mah & \\
\hline
\end{tabular}

Sumber: Data Primer

Berdasarkan uji Rank Spearman antara variable bebas dan terkait diperoleh hasil bahwa tidak terdapat hubungan antara pengetahuan dengan perilaku pada mahasiswi farmasi dengan $\mathrm{P}$-value 0,755 $(>0,05)$ dengan korelasi sebesar 0,02 berada pada tingkat hubungan yang sangat lemah
$(0,00-0,199)$ sedangkan terdapat korelasi yang signifikan antara pengetahuan dan perilaku pada mahasiswi non-farmasi P-value $0,037(<0,05)$ dengan kolerasi sebesar 0,133 pada tingkat hubungan yang sangat lemah $(0,00-0,199)$.

Tabel 3. Hasil Uji Mann-Withney Pengtahuan dan Perilaku terhadap Fakultas

\begin{tabular}{ccc}
\hline & Perilaku & Pengetahuan \\
\hline Mann-Whitney U & 25631.500 & 18336.000 \\
Wilcoxon W & 56012.500 & 48717.000 \\
Z & -2.937 & -7.625 \\
Asymp. Sig. (2-tailed) & .003 & .000 \\
\hline
\end{tabular}

a. Grouping Variable: Fakultas

Berdasarkan tabel di atas, didapatkan nilai $(p$-value $<\alpha)$ atau $(0,003<0,05)$ untuk perilaku sedangkan untuk pengetahuan $(0,000<0,005)$ maka dapat diartikan terdapat

\section{PEMBAHASAN}

\section{A. Karakteristik dan Gambaran Penggunaan Kosmetik}

Dilakukan analisis univariat pada 246 kuesioner mahasisiwi farmasi dan 246 mahasiswi fakultas Kesehatan nonfarmasi yang telah terkumpul. Hasil penelitian menunjukan semua responden berada pada rentang usia produktif menurut Pusat Data dan Informasi Kementrian Republik Indonesia tahun 2011 (15-44 tahun). hubungan yang signifikanantara fakultas dengan pengetahuan dan perilaku penggunaan kosmetik pada mahasiswi kesehatan fakultas farmasi dan non-farmasi.

Tempat mahasiswi farmasi maupun fakultas non-farmasi mendapatkan kosmetik secara online tertinggi yaitu dari aplikasi e-commerce Shopee untuk farmasi (50\%) dan-non farmasi (71,95\%) terendah adalah mendapat dari Sociolla $(9,75 \%)$ dan $(9,34 \%)$. Laporan yang dirilis oleh iPrice menunjukkan Shopee menempati posisi pertama pada daftar situs e-commerce paling populer pada kuartal terakhir di Indonesia tahun 2019 dengan jumlah pengunjung sebanyak 72 
juta pengguna per bulan sementara Sociolla berada pada peringkat ke-13 dengan jumlah pengunjung 2,7 juta perbulan. Hal ini disebabkan oleh banyaknya promo yang ditawarkan oleh Shopee sehingga tingginya ketertarikan terhadap diskon pada mahasiswi ${ }^{(9)}$

Tempat mahasiswi farmasi maupun fakultas non-farmasi mendapatkan kosmetik secara langsung tertinggi yaitu dari mall untuk farmasi $(47,56 \%)$ dan nonfarmasi $(59,34 \%)$ terendah adalah mendapat dari pasar tradisional $(1,62 \%)$ dan $(4,06 \%)$. Hal ini sejalan dengan penelitian yang dilakukan oleh Desai (2014) mall menjadi salah satu tempat untuk membeli kosmetik yang digemari mahasiswi (10). Menurut Luang dalam Agustina (2005) mall merupakan tempat remaja mengggunakan waktu luang paling disukai pada konteks waktu. Mereka biasanya datang dan melakukan berbagai aktivitas seperti belanja dan makan dengan kelompok teman sebayanya. Harga, model, dan merek umumnya sangat diperhatikan dalam pemilihan barang. Alasan utama untuk berbelanja di mall yaitu karena banyaknya pilihan. Ritzer \& Goodman dalam Aprianti (2005) menyebutkan mall kini merupakan salah satu alat konsumsi baru bagi masyarakat post-modern atau post-industri (11).

Pertimbangan responden dalam memilih kosmetik tertinggi untuk fakultas farmasi maupun fakultas Kesehatan nonfarmasi yaitu jenis kulit sebesar 47,49\% dan $53,25 \%$. Terendah untuk fakultas farmasi maupun non-farmasi adalah aroma sebanyak $16,26 \%$ dan 1,21 Jenis kulit menjadi pertimbangan memilih kosmetik sejalan dengan pernyataan Rostamailis (2005) mengenai penggunaan kosmetik harus disesuaikan dengan jenis kulit, tingkat umur dan iklim tempat tinggal sehingga efek yang diperoleh dari penggunaan kosmetik sesuai dengan apa yang diharapkan.

Dianalisis berdasarkan hasil mahasiswi fakultas farmasi menerima informasi kosmetik tertinggi bersumber dari teman/keluarga $(39,89 \%)$ sedangkan nonfarmasi bersumber dari Instagram $(41,63 \%)$, sebagian kecil bersumber dari seminar (5,69\%) dan (0,8\%). Teman sebaya merupakan faktor yang paling kuat mempengaruhi sikap mahasiswi terkait pemilihan kosmetik, dikarenakan ingin terlihat sama dengan teman sebayanya (12).

Sumber pengetahuan saat ini banyak diadopsi dari kemajuan teknologi, misalnya aplikasi social media seperti Instagram. Sebanyak 32\% responden memperoleh informasi tentang kosmetik melalui iklan sehingga tidak sedikit produk kosmetik yang memasang iklan lewat unggahan instagram menurut penelitian Lisnawati et al. (2016) ${ }^{(13)}$.

Mahasiswi farmasi maupun fakultas kesehatan non-farmasi memperoleh informasi terkait kosmetik tertinggi yaitu mengenai keamanan untuk farmasi 
$(36,58 \%)$ dan non-farmasi $(29,67 \%)$ terendah adalah informasi komposisi $(8,13 \%)$ dan (24,39\%). Hal ini menunjukan mahasiswi peduli akan keamanan kosmetik namun mahasiswi mengesampingkan komposisi dari kosmetik tersebut. Langkah yang dapat dilakukan dalam memilih kosmetik yang aman yaitu dengan memperhatikan daftar komposisi bahan sehingga konsumen dapat memilih kosmetik mana yang aman dan halal untuk digunakan menurut Admin (2012) (14). Sayangnya hingga saat ini produsen yang secara lengkap mencantumkan daftar bahan yang digunakan pada label kemasan masih sangat sedikit. Sebagian besar hanya mencantumkan khasiat tanpa keterangan bahan sama sekali atau mencantumkan bahan aktif yang terkandung dalam produk saja. Konsumen harus lebih giat lagi mencari informasi atau mencari alternatif produk lain yang lebih informative untuk menghadapi kondisi seperti ini,

\section{B. Tingkat Pengetahuan dan Perilaku Penggunaan Kosmetik}

Mahasiswi fakultas farmasi sudah memahami dengan baik terkait bahaya Merkuri. Merkuri umumnya ditambahkan sebagai bahan pengawet pada perona wajah, eye shadow, dan bedak wajah. Pada krim pemutih kulit juga kerap ditemukan merkuri. FDA dan ahli dermatologi telah menentang penggunaan merkuri dalam kosmetik. Merkuri dapat menyebabkan penyakit ginjal, kerusakan otak dan saraf, kerusakan sistem kekebalan tubuh, penyakit paru-paru dan saluran pencernaan jika terserap ke dalam tubuh. Sebagian besar mahasiswi farmasi telah mengetahui akan bahaya merkuri, tidak sedikit dari mata kuliah/pendidikan formal yang digeluti mahasiswi farmasi membahas terkait bahaya merkuri.

Mahasiswi fakultas Kesehatan nonfarmasi sudah memahami cara memastikan keamanan kosmetik sesuai anjuran yaitu dengan cara mengecek KLIK (kemasan, label, izin edar, dan kadaluwarsa). Cara ini dikeluarkan oleh Badan Pengawas Obat dan Makanan (BPOM) untuk mengenali kosmetika palsu ${ }^{(15)}$. BPOM telah mengumumkan hal tersebut melalui akun sosial media resmi BPOM salah satunya Instagram hal ini berkaitan dengan sumber informasi mahasiswi non-farmasi tertinggi diperolehdari Instagram sehingga mahasiswi kesehatan non-farmasi terpapar oleh informasi tersebut.

Sebagian besar responden mahasiswi farmasi tidak mengetahui bahwa paraben dalam kadar tertentu dapat menggagu kesuburan. Penggunaan 10 bahan dalam kosmetik telah dilarang oleh FDA, salah satunya paraben karena dapat memicu kanker kulit, kanker payudara, mengganggu endokrin, dan menurunkan jumlah sperma. Paraben sering ditemukan 
pada beberapa produk kosmetik seperti alas bedak dan lotion.

Mahasiswi Kesehatan non-farmasi kebanyakan tidak mengetahui kode registrasi kosmetik lokal. Mahasiswi farmasi mendapatkan paparan bahan ajar terkait kosmetik sehingga mungkin lebih baik pengetahuannya tentang kosmetik dibandingkan mahasiswi kesehatan non farmasi yang tidak terpapar bahan ajar tersebut. Legalitas produk merupakan hal yang sangat penting untuk diperhatikan karena saat ini pasar telah dibanjiri berbagai produk kosmetik dengan klaim khasiat dan harga yang beragam namun tidak terdaftar secara resmi di BPOM. .

Berdasarkan dari data yang terkumpul dari kuesioner yang telah disebarkan dalam bentuk pertanyaan tertutup yang terdiri dari 14 pertanyaan tentang perilaku penggunaan kosmetik pada mahasiswi farmasi sebanyak 246 responden $(67,47 \%)$ termasuk kategori cukup, sedangkan untuk mahasiswi non-farmasi $(73,98)$ cukup.

Sebagian besar mahasiswi fakultas farmasi mengecek tanggal kadaluarsa sebelum membeli kosmetik. Tanggal kadaluarsa sangat penting untuk memastikan umur dari produk kosmetik digunakan terbebas dari cemaran mikroba sehingga aman digunakan.

Mahasiswi fakultas Kesehatan nonfarmasi sebagian besar selalu melakukan cek alergi sebelum menggunakan kosmetik baru. Menurut Widana (2014) efek samping yang diketahui setelah menggunakan kosmetik yang tidak sesuai dengan jenis kulit yaitu mampu mengiritasi kulit hingga mengganggu saluran pernafasan ${ }^{(16)}$.

Sebagian besar mahasiswi farmasi dan mahasiswi kesehatan fakultas non-farmasi tidak pernah memastikan keaslian kode registrasi yang tertera pada kemasan produk dengan mengecek situs web BPOM. Menurut Bpom (2018) kosmetika yang aman dan harus memiliki izin edar atau nomor pendaftaran untuk memastikan keaslian kode registrasi dengan mengecek kode registrasi melalui situs web BPOM. Sebagian besar mahasiswi sudah mengenal KLIK namun tidak melakukan tindakan lebih lanjut yaitu pengecekan kode registrasi melalui web BPOM untuk mengetahui keabsahannya

\section{Analisis Bivariat: Korelasi Rank Spearman dan Mann-Whitney}

Berdasarkan hasil uji Rank Spearman, untuk responden mahasisiwi fakultas non farmasi didapatkan koefisien korelasi sebesar 0,133. Jika dikaitkan dengan tabel koefisien korelasi dan taksirannya dalam Sugiyono, (2015) maka koefisien korelasi sebesar 0,133 berada pada tingkat hubungan yang sangat lemah $(0,00$ - 0,199) antara pengetahuan dengan perilaku dan penggunaan kosmetik pada mahasiswi farmasi. Nilai $p$ value $<\alpha$ atau $0,037<0,05)$ menunjukkan terdapat korelasi yang signifikan antara tingkat pengetahuan 
dengan perilaku penggunaan kosmetik pada mahasiswi fakultas non farmasi sehingga semakin baik pengetahuan mengenai legalitas dan keamanan kosmetik akan memberikan peningkatan terhadap perilaku penggunaan kosmetik, sebaliknya jika pelaksanaan pengetahuan responden semakin buruk maka tingkat perilaku penggunaan kosmetik pada mahasiswi pun juga buruk.

Untuk mahasiswi fakultas farmasi didapatkan koefisien korelasi sebesar 0,02 . Jika dikaitkan dengan tabel koefisien korelasi dan taksirannya dalam Sugiyono, (2015) maka koefisien korelasi sebesar 0,02 berada pada tingkat hubungan yang sangat lemah $(0,00-0,199)$ antara pengetahuan dengan perilaku dan penggunaan kosmetik pada mahasiswi farmasi. Nilai $p$-value $>\alpha$ atau 0,755 $(>0,05)$ menunjukkan bahwa tidak terdapat korelasi yang signifikan antara tingkat pengetahuan dengan perilaku penggunaan kosmetik pada mahasiswi fakultas farmasi yang menunjukan bahwa pengetahuan mengenai legalitas dan keamanan kosmetik tidak berkorelasi dengan perilaku penggunaan kosmetik pada mahasiswi fakultas farmasi Universitas Bhakti Kencana.

Menurut Damini (2011) pemilihan dan penggunaan kosmetik sering kali tidak diimbangi dengan landasan pemahaman yang cukup dalam memilih kosmetik yang tepat (18). Pernyataan tersebut juga didukung oleh Ningsih (2016) dalam observasi terhadap mahasiswa Program Studi Tata Rias Unesa, bahwa pengetahuan mengenai kosmetik seringkali diabaikan dengan mencoba produk kosmetik yang sedang tren atau baru tanpa memperhatikan komposisi ${ }^{(19)}$. Menurut Lawrence Green (1980) dalam Notoatmodjo (2010), perilaku dapat diperngaruhi Faktor Pemungkin (enabling factor) faktor yang memungkinkan atau memfasilitasi perilaku atau tindakan seperti iklan. Faktor Penguat (reinforcing factors) faktor yang mendorong seseorang untuk berperilaku yang berasal dari orang lain misalnya petugas kesehatan, keluarga, lingkungan (20).

Berdasarkan hasil uji Mann-Withney, didapatkan nilai $(p$-value $<\alpha)$ atau $(0,003$ $<0,05)$ untuk perilaku sedangkan untuk pengetahuan $(0,000<0,005)$ maka dapat diartikan terdapat korelasi yang signifikan antara fakultas dengan pengetahuan dan perilaku penggunaan kosmetik pada mahasiswi fakultas farmasi dan nonfarmasi yang menunjukkan bahwa fakultas menentukan baik buruknya tingkat pengetahuan dan perilaku penggunaan kosmetik pada mahasiswi. Hal ini dibuktikan dengan fakultas farmasi memiliki tingkat pengetahuan yang lebih baik terkait legalitas dan keamanan kosmetik dibandingkan dengan non farmasi namun untuk perilaku sendiri fakultas non-farmasi memiliki perilaku penggunaan kosmetik yang lebih baik. Mahasiswi fakultas farmasi mendapatkan 
pembelajaran mengenai kosmetik sedangkan non-farmasi tidak. Orang yang memiliki pengetahuan baik tidak selalu berprilaku baik hal ini dapat dipengaruhi oleh faktor eksternal sejalan dengan pernyataan Rani (2014) seseorang berprilaku dipengaruhi oleh lingkungan sekitar, gaya hidup, kelassosial, status ekonomi, kepercayaan, teman dan keluarga. Faktor lingkungan memberikan peranan sangat besar terhadap pembentukan perilaku ${ }^{(21)}$.

\section{SIMPULAN DAN SARAN}

Tingkat pengetahuan dan perilaku penggunaan kosmetik pada mahasisiwi fakultas kesehatan jurusan farmasi dan nonfarmasi dikategorikan cukup. Tidak terdapat hubungan antara pengetahuan dengan perilaku pada mahasiswi farmasi sedangkan terdapat hubungan positif sangat lemah yang signifikan antara tingkat pengetahuan dan perilaku penggunaan kosmetik pada mahasiswi fakutas kesehatan non-farmasi.

Terdapat hubungan signifikan antara fakultas dengan pengetahuan dan perilaku penggunaan kosmetik pada mahasiswi fakultas kesehatan baik yang mencakup farmasi dan non-farmasi di Universitas Bhakti Kencana Bandung.

Berdasarkan hasil dan kesimpulan yang telah didapatkan, maka hal-hal yang dapat menjadi masukan kepada peneliti selanjutnya ialah: Melakukan kajian pengaruh pemberian penyuluhan terhadap pengetahuan dan perilaku penggunaan kosmetik aman dan legal terhadap mahasiswi maupun mahasiswa
Universitas Bhakti Kencana, serta melakukan kajian pengaruh factor eksternal maupun internal terhadap pengetahuan dan perilaku penggunaan kosmetik.

\section{DAFTAR PUSTAKA}

1. BPOM. Endorse Kosmetik Aman atau Menuai Bencana. 2019;

2. BPOM. Materi Edukasi Tentang Peduli Obat dan Pangan Aman. 2016; Available from: http://www.pom.go.id on 9 September 2017

3. Global Business Guide Indonesia. Overview of Indonesian Cosmetic Sector: Growing Domestic and Export Markets. 2016 [cited 2020 May 22]; Available from: http://www.gbgindonesia.com/en/manufac turing/article/2016/overview_of_indonesia n_cosmetic_sector_growing_domestic_an d_export_markets_11593.php

4. BPOM. Akhir Tahun Musnahkan dan Akhiri Peredaran Obat dan Kosmetik llegal di Bandung. 2018;

5. CNN Indonesia. Mengingat Kembali Bahaya "Racun" Kosmetik llegal [Internet]. 2018 [cited 2020 Apr 11]. Available from: https://www.cnnindonesia.com/gayahidup/20181205122420-255351278/mengingat-kembali-bahayaracun-kosmetik-ilegal

6. Kumar HH, John SF, Senith S. A Study on factors influencing consumer buying behavior in cosmetic Products. 2014;4(9):6.

7. Britton AM. The Beauty Industry's Influence on Women in Society. Honors 
Theses and Capstones 86. 2012 [cited 2020 Apr 19]; Available from: http://scholars.unh.edu/honors/86, diaksesunduh

8. Cho S, Oh S, Kim NI, Ro YS, Kim JS, Park YM, et al. Knowledge and Behavior Regarding Cosmetics in Koreans Visiting Dermatology Clinics. Ann Dermatol. 2017;29(2):180.

9. iPrice insight. Find Out E-comerce Competion in Indonesia [Internet]. iPrice; 2020 [cited 2020 May 19]. Available from: https://iprice.co.id/insights/mapofecommer ce/

10. Desai K. A Study on Consumer Buying Behaviour of Cosmetic Products in Kolhapur. 2014;1(10):11.

11. Aprianti R. Pengaruh Majalah Remaja Terhadap Gaya Hidup Remaja Putri. Inst Pertan Bogor. 2005;

12. Yonita AS. Hubungan Pengetahuan, Sikap terhadap Mahasiswa untuk Bertindak Menggunakan Kosmetik Mengandung Merkuri (Hg). Bagian Promosi Kesehat dan IImu Perilaku Fak Kesehat Masy Univ Jember. 2015;136.

13. Lisnawati D, Wijayanti A, Puspitasari A. Tingkat Pengetahuan dan Persepsi Bahaya Kosmetika Yang Mengandung Bahan Pemutih di Smk Negeri 4 Yogyakarta. 2016;13(1):13.
14. Admin. Panduan Memilih Kosmetik Aman dan Halal. 2012;

15. Badan POM RI. Keputusan Kepala Badan Pengawas Obat dan Makanan Republik Indonesia Nomor Hk.00.05.4.1745 Tentang Kosmetik. In Badan Pengawas Obat dan Makanan Republik Indonesia; 2002.

16. Widana GAB. Gede Agus Beni Widana, Analisis Obat, Kosmetik dan Makanan. Yogyakarta: Graha Ilmu; 2014. 53 .

17. Bpom. Laporan Kinerja Badan Pengawas Obat dan Makanan Republik Indonesia. 2018;

18. Daminik T. Persepsi Remaja Putri di Kota Ambon Tentang Resiko Terpapar Kosmetik Berbahaya dan Perilakunya dalam Memilih dan Menggunakan Kosmetik. 2011;27.

19. Ningsih A. Pengaruh Pengetahuan Kosmetika dan Persepsi Mahasiswa Tata Rias Terhadap Keputusan Pembelian Produk BB Cream Untuk Penampilan Diri. Univ Surabaya. 2016;

20. Notoatmodjo S. IImu Perilaku Kesehatan. Jakarta: Rineka Cipta; 2010. 13-29 p.

21. Rani P. Factors Influencing Consumer Behaviour. 2014;10. 